\title{
Proč psát kazuistiku očima mladého onkologa
}

\author{
Miroslav Žiaran \\ Klinika onkologie a radiologie Fakultní nemocnice, Hradec Králové
}

Multicentrická randomizovaná dvojitě zaslepená studie fáze III. Slova, která v současné onkologii nabyla formu zaříkávadel, pritahující onkology na kongresy, nutící plátce péče k úhradám nových léčiv a nových indikací léčiv již hrazených a pacientům poskytují pocit jistoty a bezpečí v průběhu léčby.

Předmětem tohoto sdělení nejsou definice ani správné postupy psaní kazuistiky, nakonec se ani necítím být kvalifikován jimi čtenáře zatěžovat. Cílem je nabídnout pohled mladého lékaře, který při běžné práci plné administrativy rád přemýšlí nad neznámým a novým, což nakonec studium medicíny slibovalo, ale praxe jaksi limituje.

Cesta v postgraduálním vzdělávání je trnitá. A mám na mysli tu končící atestací, i tu končicí obhajobou disertační práce. Na úplném počátku praxe se nelze vyhnout konzultaci s medicínskými databázemi, kde mladý lékař v anxietě hledá prípady podobné těm, které před ním leží či stojí. Pokud není odpověd’ k nalezení $\checkmark$ guidelinech, dobře napsaná kazuistika může poskytnout úlevu.

Školitel dřive či později požaduje sepsání prehledového článku, což, jak mladý onkolog brzy zjistí, je bez zkušeností a patřičného vedení úkol, který nedokáže splnit. Při čtení literatury zjistí, že v tom není sám a poslechne doporučení začít po malých krůčcích, kde prvním z nich je publikace kazuistiky. Nejenže se při psaní přiučí praktickým dovednostem, ale na cestě k poznání ukojí svou zvědavost, získá netušené kontakty a jako odměna někdy přijde i publikace, krátká přednáška a záznam do životopisu.

Platí, že v oněch studiích s mnoha prívlastky jsou pacienti sice randomizováni, na druhé straně jsou ale zařazeni dle přesně stanovených vstupních kritérií. V praxi taková kritéria při zahájení léčby obvykle nestanovujeme, ani pacienti většinou tolik nespolupracují a stěžuji si na nežádoucí účinky, jež ve studii a ani v SPC uvedeny nejsou. Nebo spolupracují ještě méně a vyvinou 2 typy nádorového onemocnění. $\checkmark$ těchto př́padech dle mého pozorování již i zkušený onkolog sáhne po nejbližším počítači a hledá podobné případy ve světě doufaje v nápovědu. 